\title{
A Survey of Cellulolytic Bacteria in Qinghai-Tibet Plateau: Isolation, Identification and Characterization
}

\author{
Ling Lin*, Na Qin, Miaomiao Chen, Rui Shi, Liu Feng, Duntao Huang, Qing Yang \\ Institute of Molecular Biology and Biotechnology and the Research Center of Life Omics and Health, \\ Provincial Key Laboratory of the Conservation and Exploitation Research of Biological Resources, \\ College of Life Sciences, Anhui Normal University, Wuhu, Anhui, P.R. China
}

Received: 1 March 2019

Accepted: 29 May 2019

\begin{abstract}
The Qinghai-Tibet Plateau in China is the highest regions on earth, with very special geographic and climatic properties. For historical reasons, until now very limited biological research has been conducted on this area. While cellulolytic bacteria are of great importance for environmental carbon cycling and developing human usable cellulase, this study gives a preliminary survey of these bacteria in this area. 24 cellulolytic strains showing high cellulolytic activities were isolated and further identified by 16s rDNA sequencing. Most of these strains belong to the genus Lysinibacillus sp., Streptomyces sp., Agrobacterium sp., Bacillus sp. and Microbacterium sp. It is believed that these strains should serve as very good candidates for future industrially used cellulase development.
\end{abstract}

Keywords: Qinghai-Tibet Plateau, cellulolytic bacteria, cellulase acitvity

\section{Introduction}

The Qinghai-Tibet Plateau in the southwestern China is the highest region on earth, with an average elevation of 4500 meters, and is the so-called "roof of the world". It is highly hypoxic and shows unique climate characteristics, with an average annual rainfall of 140 $\mathrm{mm}$, a long cold winter, an average annual temperature of $1^{\circ} \mathrm{C}$ and a huge temperature difference between day and night. It also has a complex geographic property including mountains, glaciers, alpine lakes and alpine swamps $[1,2]$. Due to its environmental specialty, it has

*e-mail: linling8@ahnu.edu.cn always been suggested to have unique biodiversity and serve as a good reservoir for developing the organismderived resources such as medicinal additives [3] and industrial enzymes [4, 5]. However, unfortunately, until now, its biodiversity and bio-resources have not been well investigated and known.

Cellulolytic bacteria are a group of bacteria that can degrade cellulose - the most abundant carbon resource on earth [6]. They either freely live in the environment and degrade the environmental cellulose (such as forest deposits and agricultural wastes) or dwell in the animal gastrointestinal tract and assist in decomposing the cellulose-food intake. These bacteria are shown to be ecologically significant because of their essential role in global carbon-recycling. They are also industrially important because they serve as very good 
resources for developing cellulases, used in paper, food or the bioenergy industry [7-9]. With this background, this study focuses on bacterial diversity toward bioprospecting for cellulolytic bacteria from different geographical locations of the Qinghai-Tibet Plateau.

\section{Materials and Methods}

\section{Site Description and Sampling}

A total of 12 soil samples were collected from the different habitats of the Qinghai-Tibet Plateau, including wetland, sandland, grassland, tundra and mountainous land (Fig. 1). The soil samples (5-10 centimeters below the surface) were collected in sterile $50 \mathrm{~mL}$ tubes from these regions, and subsequently placed in coolers and transferred to a lab for further research.

\section{Screening Bacterial Strains}

In order to screen the cellulolytic bacteria, $1 \mathrm{~g}$ of each soil sample from different areas of the Qinghai-Tibet Plateau was first suspended into $99 \mathrm{ml}$ distilled water. Later, a $0.1 \mathrm{ml}$ diluted soil-water mixture was spread onto the minimal media plate containing CMC-Na (sodium carboxymethylcellulose), a synthetic cellulose analogue, as the sole carbon source. The media was so-called CMC enrichment media and its components (1 L) were: $\mathrm{CaCl}_{2} 0.1 \mathrm{~g}, \mathrm{MgSO}_{4} 0.1 \mathrm{~g}$, (NH4) ${ }_{2} \mathrm{SO}_{4} 2.0 \mathrm{~g}$, $\mathrm{KH}_{2} \mathrm{PO}_{4} 0.5 \mathrm{~g}, \mathrm{~K}_{2} \mathrm{HPO}_{4} 2.0 \mathrm{~g}, \mathrm{NaCl} 6 \mathrm{~g}, \mathrm{CMC}-\mathrm{Na} 0.5 \%$, and agar $1.5 \mathrm{~g}, \mathrm{pH}$ 7.0. The colonies showing good growth were then picked and further spotted the two CMC enrichment media plates (for activity detecting and strains preservation, respectively), simultaneously and grown at $28^{\circ} \mathrm{C}$ for 3 days. One of the two plates was then used for detecting the cellulolytic activity using the
Congo-red method [7]. Briefly, the plate was stained by $0.1 \%(\mathrm{w} / \mathrm{v})$ Congo-red water solution for $10 \mathrm{~min}$ and destained by $1 \mathrm{M} \mathrm{NaCl}$. The colony showing halos on the plate (colony diameter and halo diameter were measured and the dates represent the cellulolytic activity of the strain) was then picked from the other plate of the two and used for further analysis.

\section{Phylogenetic Analysis of 16S rDNA Gene Sequences}

The obtained strains showing different cellulolytic activity or morphology were cultured in LB broth and the genomic DNA was extracted with AxyPrep Bacterial Genomic DNA Miniprep Kit (Axygen, USA) according to the manufacturer's instructions. Then, the 16S rDNA gene was PCR-amplifyed and purified by an AxyPrep DNA Gel Extraction Kit (Axygen, USA), and subsequently sequenced by using universal primers. All the DNA sequences were analyzed and aligned using the CLUSTALX program, and neighborjoining algorithms were used for the construction of a phylogenetic tree by MEGA 7.0 software [10]. Bootstrap analysis was performed by employing 1,000 replicate data sets in order to evaluate the confidence limits of the branching.

\section{Production of Enzyme}

The strains were overnight-cultured in LB-CMC medium (LB broth with $0.5 \% \mathrm{CMC}$ ) at $28^{\circ} \mathrm{C}, 200 \mathrm{rpm}$, and $1 \%$ seed culture were progressively transferred and inoculated in fresh LB-CMC medium under the same conditions. The culture supernatant at stationary phase of cell growth (24-48 hrs) was harvested by centrifuging at $4000 \mathrm{rpm}$ for $10 \mathrm{~min}$ and was finally used for cellulase activity assay.

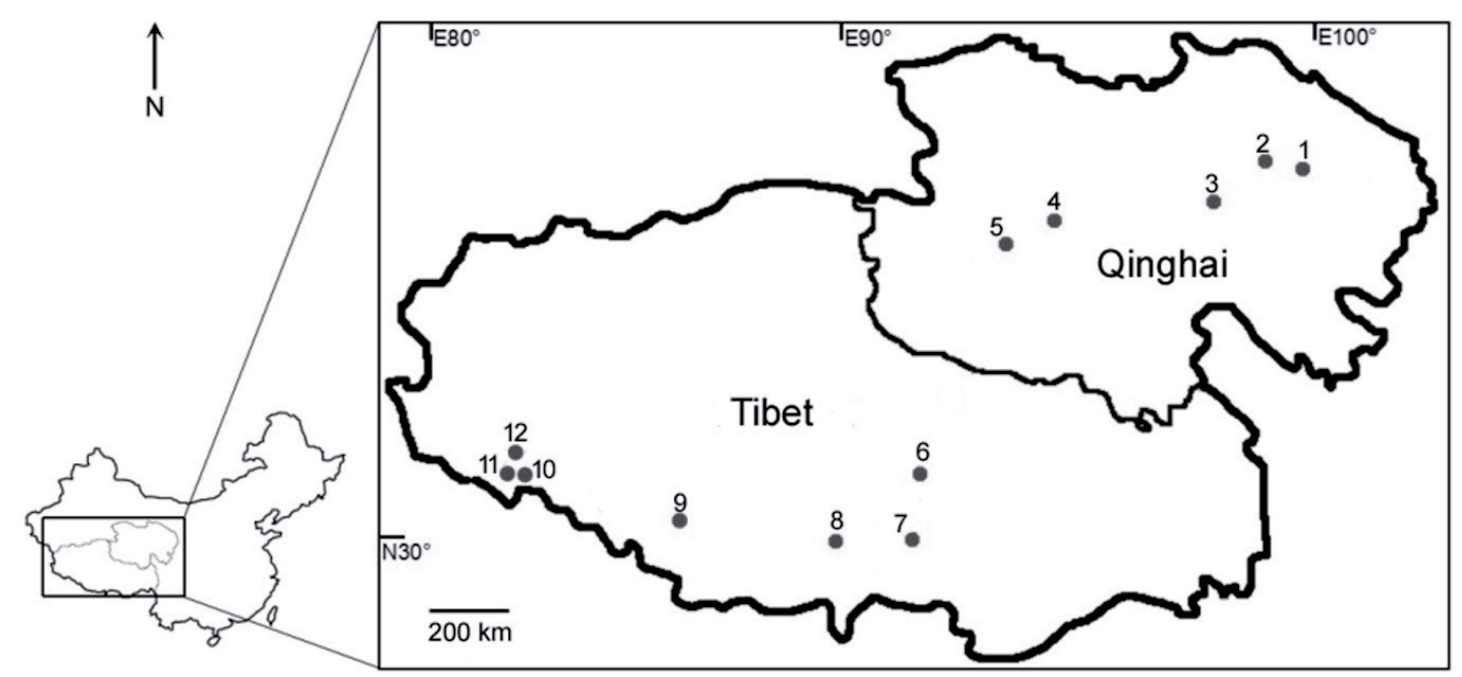

Fig. 1. Map showing sampling area in Qinghai-Tibet Plateau.

Twelve soil samples were collected from different geographic regions as follows: 1. Gonghe, Qinghai; 2. Chaka, Qinghai; 3. Dulan, Qinghai; 4. Geermu, Qinghai; 5. Qumalai, Qinghai; 6. Dangxiong, Tibet; 7. Qushui, Tibet; 8. Rikaze, Tibet; 9. Saga, Tibet; 10. Pulan, Tibet; 11. Pulan, Tibet; and 12. Pulan, Tibet 


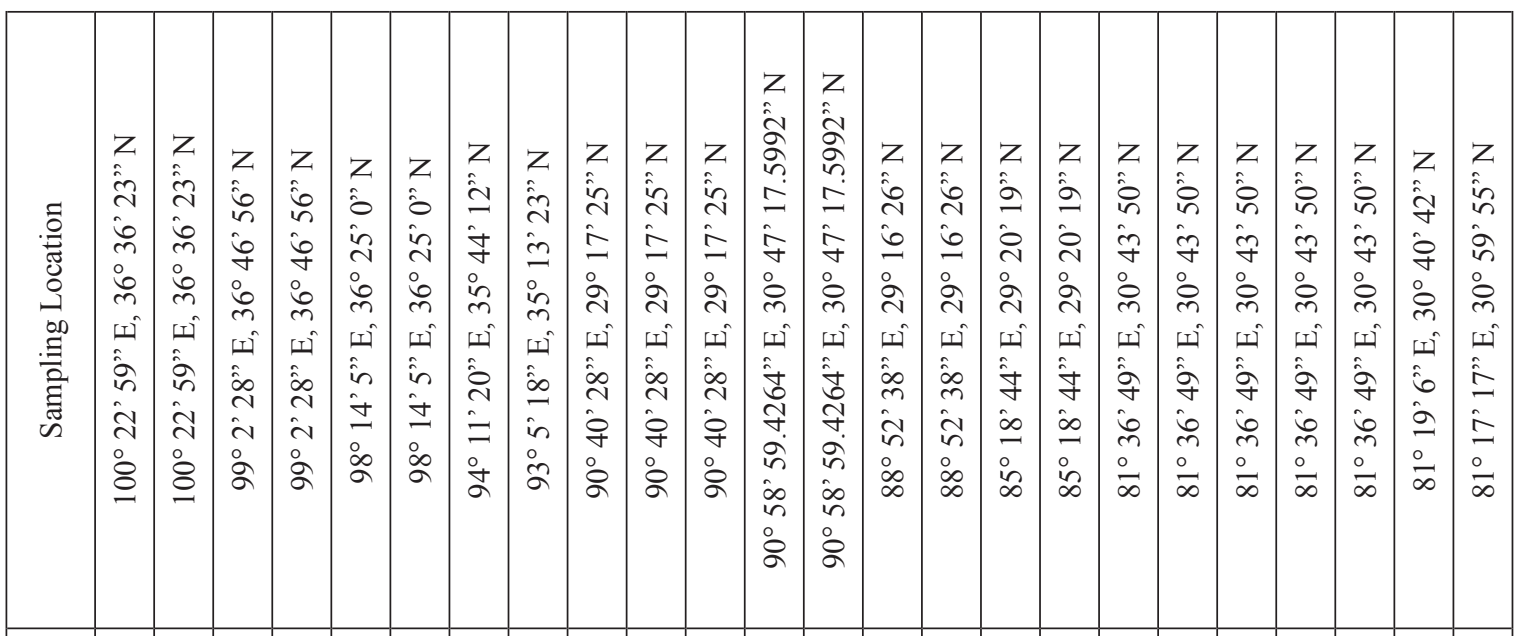

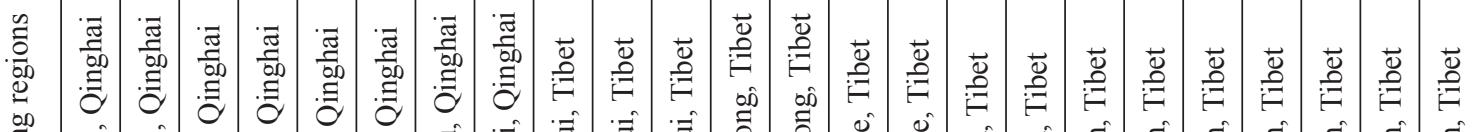

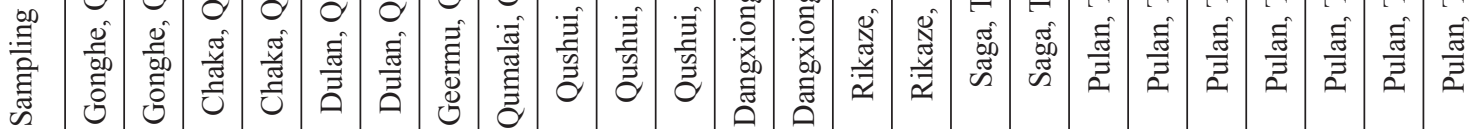

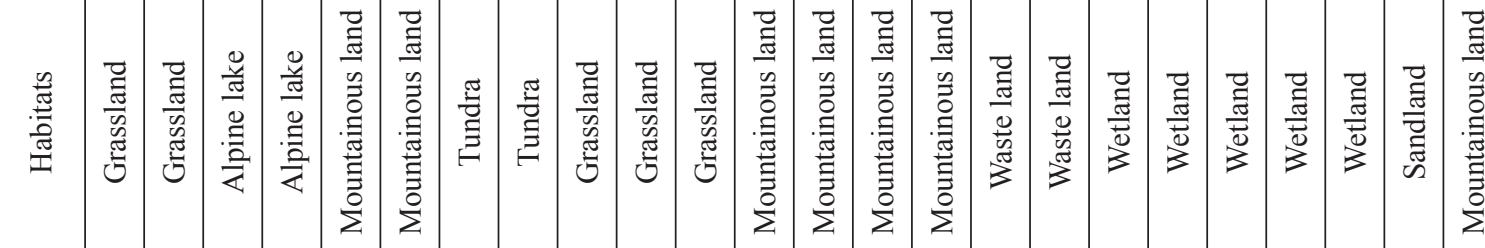

ए

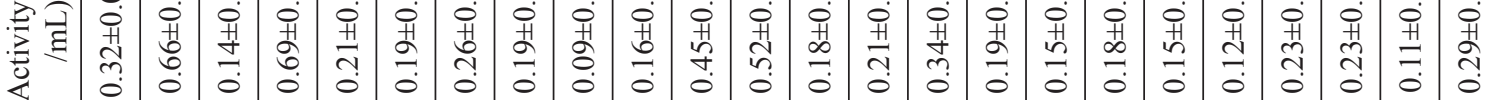

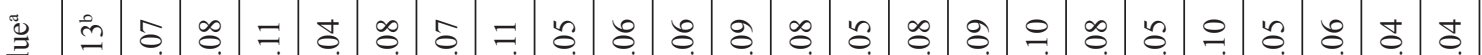

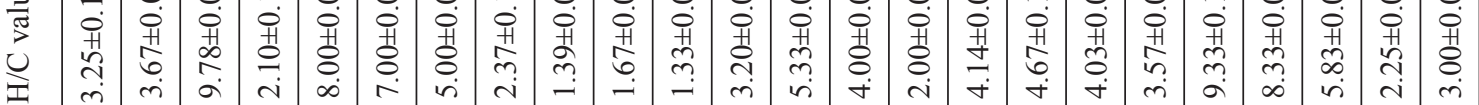

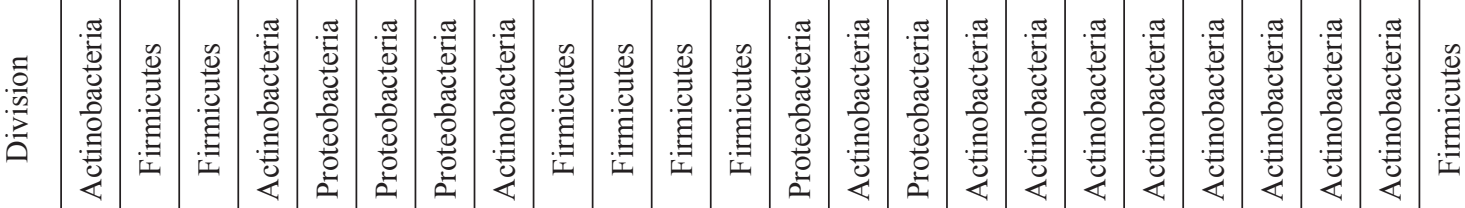




\section{Enzyme Assay}

The cellulase activities assay was carried out as described by Lin with some modifications [11]. The reaction contained $50 \mu \mathrm{L} 0.5 \% \mathrm{CMC}$ (Sigma) in $100 \mathrm{mM}$ sodium acetate buffer $(\mathrm{pH} 5.0)$ and $50 \mu \mathrm{L}$ enzyme solution. After incubation at $40^{\circ} \mathrm{C}$ for $30 \mathrm{~min}$, $100 \mu \mathrm{L}$ dinitrosalicylic acid reagent (DNS) was added and the mixture was placed in a boiling-water bath for $5 \mathrm{~min}$ and then diluted to $1 \mathrm{~mL}$. Absorbance was measured at $540 \mathrm{~nm}$ and one unit of the activity was defined as the quantity of enzyme releasing $1 \mu \mathrm{mol}$ reducing sugar per min at $40^{\circ} \mathrm{C}$ (glucose as a standard).

\section{Results and Discussion}

\section{Soil Samples Description}

In order to obtain bacteria with unique properties, seven unique habitats belonging to the different geographic regions in Qinghai-Tibet Plateau were selected as sample sites (Fig. 1 and Table 1). The diversity of microorganisms of the Qinghai-Tibet Plateau varies drastically with respect to climate conditions, temperature, soils and particularly the higher altitudes. This area also has several unique habitats such as glacial ice, permafrost, tundra, wetlands, and alpine lakes. Most of the microbiota in this region are cold-adapted and might serve as a good candidate for developing medicinal additives and industrial enzymes $[12,13]$.

\section{Phylogenetic Analysis of Bacterial Diversity}

In this study, 24 strains with the highest cellulolytic activity were further identified by $16 \mathrm{~s}$ rDNA sequencing (Table 1). The nearest phylogenetic neighbor of all 24 strains were identified through BLAST analysis, and subsequently the phylogenetic tree was constructed by using the CLUSTALX program and MEGA 7.0 software (Fig. 2). The study revealed 11 different genera that belonged to three divisions, namely Actinobacteria, Firmicutes and Proteobacteria. It was found that most of these strains, which were classified in the division of Actinobacteria, formed among the genera Streptomyces, Agrobacterium, Jonesia, Lentzea, Zhihengliuella and Microbacterium. Other following seven strains spread among the genera Lysinibacillus and Bacillus in the phylum of Firmicutes. And the remaining four micro-bacteria including the genera Agrobacterium, Phyllobacterium and Pseudomonas were classified in Proteobacteria. These results were in concurrence with the previous study in the Himalayan Mountains, where Firmicutes, Actinobacteria, and Proteobacteria were the most common phylum present in the plateau area $[14,15]$. Most noteworthy, it was first report regarding cellulase activities in the Zhihengliuella halotolerans, Lentzea sp. species isolated from the Qinghai-Tibet Plateau. While limited research has focused on cellulolytic bacteria from the Qinghai-Tibet Plateau, this study thus provides very useful insights about the biodiversity of cellulolytic bacteria in this area. The cellulolytic bacteria isolated from this special climatic and geographic area should

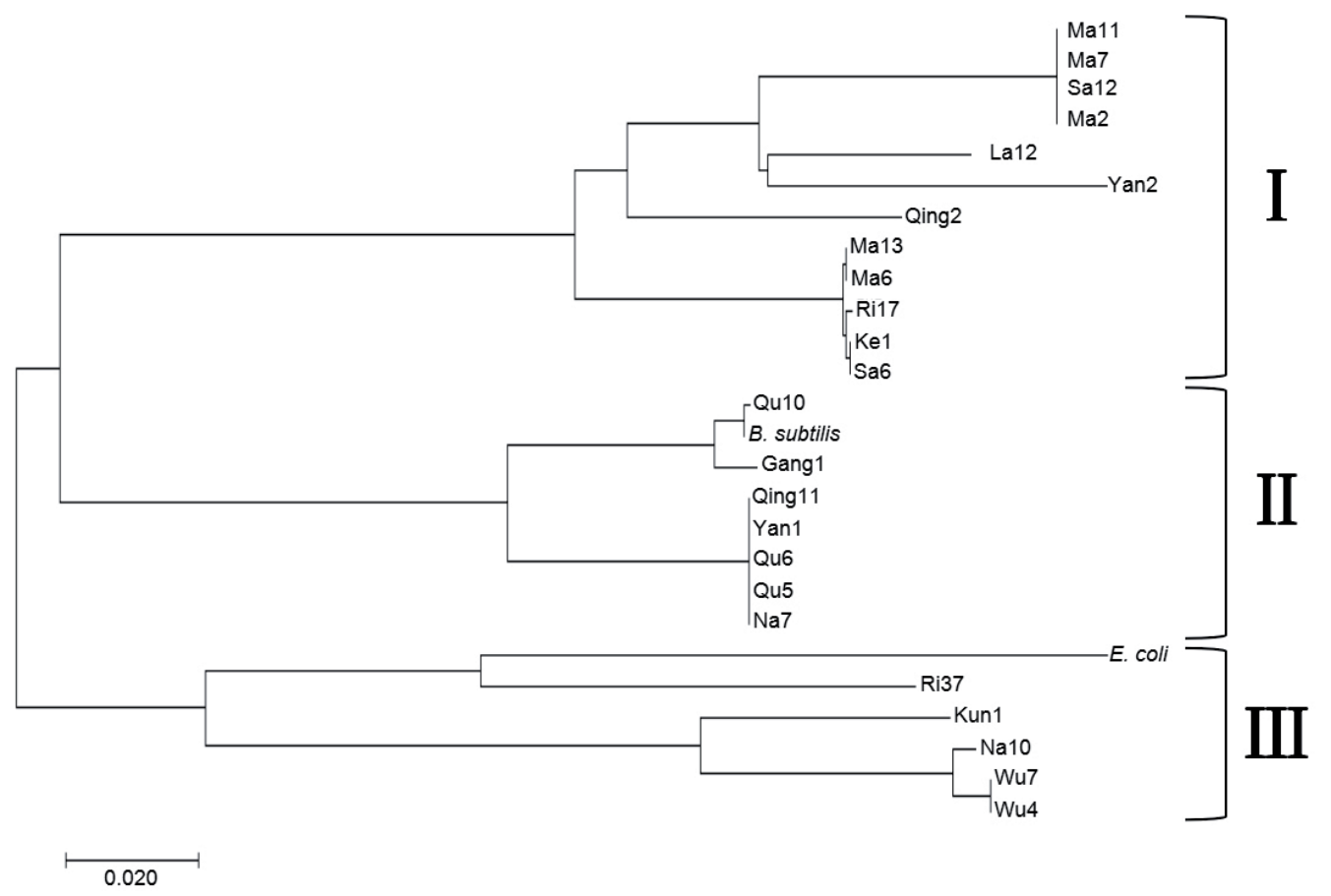

Fig. 2. Phylogenetic Analysis of Bacterial Diversity.

Neighbor-joining tree based on the 16S rDNA sequences showing the phylogenetic relationship of the bacterial isolates belonged to three divisions, namely Actinobacteria (I), Firmicutes (II) and Proteobacteria (III); Escherichia coli (J01859.1) and Bacillus subtilis (NR_102783) were taken as related groups 
serve as very good candidates for future industrially used cellulase development $[8,11,16]$.

\section{Cellulolytic Activities of the Isolates}

Congo red staining/de-staining showed that 24 strains have considerable halos on the plate, due to variable colony size of each strain after growth, judging the cellulolytic activity solely by halo size might not accurately reflect their cellulolytic activity (Table 1). An "HC" value, halo size/colonly size was further used to evaluate the cellulolytic activity of each strain. It was found that although $\mathrm{HC}$ value showed certain positive correlation with halo size, this correlation was not very strong. Notably, the "HC" value champion was the strain Yan1, with a number of 9.78 and the lowest $\mathrm{HC}$ value was owned by the strain Qu5, with a number of 1.39. Nevertheless, while it is very hard to know how cellulase was produced and how these cellulases were running and degrading the CMC during the strain growth, it is very hard to simply rank the cellulolytic activity of each strain by "halo size" or "HC" value. Therefore, here the strains with considerable cellulolytic halos were subjected to liquid culture for cellualse activities. As shown in Table 1, Yan2 and Qing11, identified as Jonesia quinghaiensis and Lysinibacillus fusiformis respectively, demonstrated the highest cellulase activities (0.66-0.69 U/mL) compared with other isolates.

It should also be noted that some genetically identical strains isolated from the different habitats and areas were identified as the same species by $16 \mathrm{~s}$ rDNA sequencing, but totally different "HC" value and cellulase activities. For example, Qing11, Yan1, Qu5, Qu6 and Na7 both belonged to Lysinibacillus fusiformis, but showed a quite different "HC" and cellulase value. Similarly, Microbacterium sp. Sa12 and Ma2 also showed a quite lower "HC" value compared with Ma7 and Ma11. Therefore, the diversity of bacteria seems not to correlate with the cellulase activities and production. Nevertheless, the different activities and properties of the enzyme from the same species could indeed be due to the distinct geographical habitat with respect to cold climate conditions, low air pressure and low rate of vegetation coverage [5, 10, 17]. Consequently, these distinct microbial enzymes explored from these unique habitats could have a wide scope for industrial applications [18].

Furthermore, the cellulase gene $J q C e l 5 A$ had been cloned from Yan2 strain and functionally reported [11], and due to the report regarding cellulase genes from Zhihengliuella halotolerans and Microbacterium sp. species, these two strains were selected for further study that is currently under evaluation.

\section{Conclusions}

Our study employed the cellulase activity screening method and molecular biotechnology to identify and classify the cellulase-producing microorganisms from different habitat soils in the Tibetan Plateau. Through a cultivable screening approach, we obtained 24 distinct isolates in 12 soils samples collected from different geographical areas of the Qinghai-Tibet Plateau, in which Firmicutes, Actinobacteria and Proteobacteria were found to be the predominant phylum. Furthermore, the species Zhihengliuella halotolerans, Lentzea sp. and Microbacterium were identified from the QinghaiTibet Plateau for the first time through this study, which would provide basic information for the species to be used potentially in industrial applications, and these environmentally tolerant and psychrophilic microorganisms might be of economic significance in biotechnology, agriculture, and medicine $[3,6,13]$.

\section{Acknowledgements}

This study was supported by grants from the Key Laboratory of Biotic Environment and Ecological Safety in Anhui Province, Innovation Team of Scientific Research Platform in Anhui Universities, and the Provincial Key Project of Natural Science Research for Colleges and Universities of Anhui Province of China (KJ2017A321).

\section{Conflict of Interest}

The authors declare no conflict of interest

\section{References}

1. HU W., ZHANG Q., TIAN T., LI D., CHENG G., MU J., WU Q., NIU F., AN L., FENG H. Characterization of the prokaryotic diversity through a stratigraphic permafrost core profile from the Qinghai-Tibet Plateau. Extremophiles. 20 (3), 337, 2016.

2. RUI J., LI J., WANG S., AN J., LIU W.T., LIN Q., YANG Y., HE Z., LI X. Responses of Bacterial Communities to Simulated Climate Changes in Alpine Meadow Soil of the Qinghai-Tibet Plateau. Appl. Environ. Microb. 81 (17), 6070, 2015.

3. VENKATACHALAM S., GOWDAMAN V., PRABAGARAN S.R. Culturable and culture-independent bacterial diversity and the prevalence of cold-adapted enzymes from the Himalayan mountain ranges of India and Nepal. Microb. Ecol. 69 (3), 472, 2015.

4. LONG H., WANG Y., CHANG S., LIU G., CHEN T., HUO G., ZHANG W., WU X., TAI X., SUN L., ZHANG B. Diversity of crude oil-degrading bacteria and alkane hydroxylase (alkB) genes from the Qinghai-Tibet Plateau. Environ. Monit. Assess. 189 (3), 116, 2017.

5. AQVIST J., KAZEMI M., ISAKSEN G.V., BRANDSDAL B.O. Entropy and Enzyme Catalysis. Accounts. Chem. Res. 50 (2), 199, 2017.

6. PERCIVAL ZHANG Y.H., HIMMEL M.E., MIELENZ J.R. Outlook for cellulase improvement: screening a nd selection strategies. Biotechnol. Adv. 24 (5), 452, 2006. 
7. ZHANG S., SHAN D., LIU X., SUN M. CelluloseDegrading Strains: their Screening and Application to Corn Straw in Low-Temperature Environments. Pol. J. Environ. Stud. 27 (5), 2349, 2018.

8. ZARAFETA D., KISSAS D., SAYER C., GUDBERGSDOTTIR S.R., LADOUKAKIS E., ISUPOV M.N., CHATZIIOANNOU A., PENG X., LITTLECHILD J.A., SKRETAS G., KOLISIS F.N. Discovery and Characterization of a Thermostable and Highly Halotolerant GH5 Cellulase from an Icelandic Hot Spring Isolate. PloS One. 11 (1), e0146454, 2016.

9. NKOHLA A., OKAIYETO K., NWODO U.U., MABINYA L.V., OKOH A.I. Endoglucanase and Xylanase Production by Chryseobacterium Species Isolated from Decaying Biomass. Pol. J. Environ. Stud. 26 (6), 2651, 2017.

10. KUMAR S., STECHER G., TAMURA K. MEGA7: Molecular Evolutionary Genetics Analysis Version 7.0 for Bigger Datasets. Mol. Biol. Evol. 33 (7), 1870, 2016.

11. LIN L., LIU X., ZHOU Y., GUAN L., HE J., HUANG W. A novel $\mathrm{pH}$-stable, endoglucanase ( $\mathrm{JqCel} 5 \mathrm{~A})$ isolated from a salt-lake microorganism, Jonesia quinghaiensis. Electron. J. Biotechn. 24, 56, 2016.

12. MARGESIN R.,MITEVA V. Diversity and ecology of psychrophilic microorganisms. Res. Microbiol. 162 (3), 346, 2011.

13. SIDDIQUI K.S.,CAVICCHIOLI R. Cold-adapted enzymes. Annu. Rev. Biochem. 75, 403, 2006.
14. YADAV A.N., SACHAN S.G., VERMA P., KAUSHIK R., SAXENA A.K. Cold active hydrolytic enzymes production by psychrotrophic Bacilli isolated from three sub-glacial lakes of NW Indian Himalayas. J. Basic Microb. 56 (3), 294, 2016.

15. SHIVAJI S., PRATIBHA M.S., SAILAJA B., HARA KISHORE K., SINGH A.K., BEGUM Z., ANARASI U., PRABAGARAN S.R., REDDY G.S., SRINIVAS T.N. Bacterial diversity of soil in the vicinity of Pindari glacier, Himalayan mountain ranges, India, using culturable bacteria and soil 16S rRNA gene clones. Extremophiles. 15 (1), 1,2011

16. MELO I.S., ZUCCHI T.D., SILVA R.E., VILELA E.S., SABER M.L., ROSA L.H., PELLIZARI V.H. Isolation and characterization of cellulolytic bacteria from the Stain house Lake, Antarctica. Folia Microbiol. 59 (4), 303, 2014.

17. DUARTE A.W.F., DOS SANTOS J.A., VIANNA M.V., VIEIRA J.M.F., MALLAGUTTI V.H., INFORSATO F.J., WENTZEL L.C.P., LARIO L.D., RODRIGUES A., PAGNOCCA F.C., PESSOA JUNIOR A., DURAES SETTE L. Cold-adapted enzymes produced by fungi from terrestrial and marine Antarctic environments. Crit. Rev. Biotechnol. 1, 2017.

18. MARX J.C., COLLINS T., D'AMICO S., FELLER G., GERDAY C. Cold-adapted enzymes from marine Antarctic microorganisms. Mar. Biotechnol. 9 (3), 293, 2007. 